\title{
Perceptions of Undergraduate Students about Three Teaching Methods; Lectures, Practical and Problem Based Learning Sessions
}

\author{
Mohammed Elimam Ahamed Mohammed ${ }^{1,2}$ \\ ${ }^{1}$ Department of Chemistry, Faculty of Science, King Khalid University, Abha, Saudi Arabia \\ ${ }^{2}$ Nuclear Applications in Biological Sciences, Sudan Atomic Energy Commission, Sudan
}

\section{Email address:}

mohammedelimam@yahoo.com,meaahmad@kku.edu.sa

\section{To cite this article:}

Mohammed Elimam Ahamed Mohammed. Perceptions of Undergraduate Students about Three Teaching Methods; Lectures, Practical and Problem Based Learning Sessions. Education Journal. Vol. 4, No. 1, 2015, pp. 15-19.

doi: $10.11648 /$ j.edu.20150401.14

\begin{abstract}
From biochemical education point of view, it is so difficult to make the biochemistry more interesting by adopting one teaching method. The aim of this article is to investigate the perceptions of the undergraduate students of the department of chemistry at king Khalid university about three teaching methods; lectures, practical and problem based learning sessions. A second objective is to compare the students perceptions to their performance in three different exams depending on the information gained from the three teaching methods. 63 students were registered for the basic biochemistry course at the faculty of science- King Khalid University. At the end of the course and before the final exam, the students perceptions about the three teaching methods were investigated through a simple questionnaire composed of four best answer Questions. However, 59 students responded to the questionnaire. The questionnaire was analyzed and its results were compared to the students performance results in the three different final exams. Regarding the students perceptions about the three teaching methods; 22 students (37.3\%)stated that the practical sessions were the best teaching method for them followed by the problem based learning sessions $(19,32.2 \%), 7$ students $(11.9 \%)$ preferred the lectures while 11 students $(18.6 \%)$ expressed that the three teaching methods were not their favorite methods. Concerning the recalling of the information; 24 (40.6\%) expressed that the information of the problem based learning sessions was easy to recall and difficult to forget followed by the information of the practical sessions $(17,28.8 \%)$ and lectures $(9,15.3 \%)$ and $9(15.3 \%)$ stated the information of all the three methods was difficult to recall and easy to forget. The performance of the students in the final exams and their perceptions were comparable since the success percentage in the practical and problem based learning sessions and lectures were $95.2 \%, 82.5 \%$ and $82.5 \%$ respectively. Although the practical and the problem based learning sessions were the best teaching methods for the bulk of the students $(41,69.5 \%)$, it is better to follow more different teaching methods to satisfy the majority of the students and to obtain better student performance.
\end{abstract}

Keywords: Problem Based Learning, Practical Sessions, Lectures, Perceptions, Performance

\section{Introduction}

The department of chemistry at king Khalid university is responsible for teaching basic biochemistry course for the students of chemistry and biology of the faculty of science and the biology and chemistry students of the faculty of education.

The biochemistry course contains the chemistry of biomolecules and their functions, the digestion and absorption and metabolism. The credit hours of the course were three credit hours and the course contents were the same for all the students.

The teaching methods of biochemistry were teacher centered methods; lectures and practical sessions only. Most of the students feel that the biochemistry course is irrelevant to their faculty curriculum, boring, difficult to understand and easily forgotten subject. The performance of the students in the exams reflect their feeling; the highest success percentage was $75 \%$. This situation pushed the department to introduce student centered teaching methods like seminars, problem based learning and tutorials. 
According to the literature, student centered teaching methods are more effective than the traditional teacher centered teaching methods and the performance of the students in the exams of self learned information (student centered) like the problem based learning is better than their performance in the exams of the spoon feed information (teacher centered) [1].

Lectures are the traditional and teacher centered teaching method. Lectures are characterized by active teacher and passive students [2]. However, some efforts to make the lectures more interactive have been suggested [3].

Practical sessions can be conducted in a traditional method (teacher centered) or by engaging the students in obtaining the knowledge by themselves and the tutors act as facilitators $[4,5]$.

Problem based learning is one of the student centered teaching methods and it caused a wide spread change in the higher education [6]. However, the problem based learning was first suggested by Barrows and Tamblyn since 1960 and it was popularized after they published a paper in 1980 [7]. Problem based learning was adopted firstly in the medical schools and followed by the faculties of education, engineering, agriculture and science in different countries including USA, Europe, Canada, Singapore and Australia [6].

Problem Based Learning method is organized to investigate, explain and resolute a simulated problem. PBL is one of the small group teaching methods and it is student centered in which the teacher act as facilitator to solve specific problem. The PBL tutorial process has six steps; they receive a problem scenario from a facilitator, they study and identify the facts of the problem, they generate a possible hypothesis to solve the problem, identify the knowledge deficiencies (learning issue), the students work hard to fill the knowledge gap in a Self Directed Learning style (SDL), they apply their new knowledge to evaluate their hypothesis and to solve the problem finally they write an abstract (report) about the problem. The teacher major role is to make sure that all the students participate in solving the problem and help them to collaborate[8].

A hybrid teaching method between lectures and problem based learning have been proposed and implemented by Jiqin Lian and Fengtian He and Andis Klegeris and Heather Hurren [9, 10].

The objectives of this article are to

1. Investigate the perceptions of the students of the faculty of science at King Khalid University about three teaching methods; lectures, practical and problem based learning sessions, followed in teaching the basic biochemistry course.

2. Compare the students perceptions to their performance in the final exams of the basic biochemistry course.

\section{Material and Method}

\subsection{Study Population}

Sixty three students were registered for the basic biochemistry course, 59 of them responded to the questionnaire. The students were from different backgrounds and levels; chemistry (semester 8), biology (semester six) and education (semester 4).

\subsection{Procedure}

The basic biochemistry course was implemented following three teaching methods lectures in which the teacher was the major player and the students were passive, practical sessions, also dominated by the facilitator and the student centered teaching method; the problem based learning sessions (PBL). The water, $\mathrm{pH}$ and buffers, carbohydrates, lipids, amino acids and proteins, nucleotides and nucleic acids and enzymes were delivered as lectures, the practical were 8 associated with the qualitative tests of all the biomolecules and the vitamins were delivered as 5 problem based learning sessions, the first was for the general characteristics of the vitamins, the second was for vitamin A (night blindness), the third was associated with vitamin $C$ (Scurvy), the fourth was specified for vitamin B12 and folic acid (Anemia) and the fifth session was for vitamin $\mathrm{D}$.

Each problem based learning session lasted for 2 hours and the students were divided to a number of small groups depending on the number of the questions in each problem. Each problem has a leader student responsible for dividing the students into small groups and leading the problem based learning session and a clerk responsible for summarizing the answers of all the groups in one report. The leader and the clerk students were responsible for copying the problem report and distributing it between the students. The academic resources were three biochemistry books and the internet.

A simple questionnaire was established to investigate the perceptions of the students about the three teaching methods; lectures, practical sessions and problem based learning sessions. The questionnaire was composed of four best answer questions with four options each. The first question was tackling the best teaching method, the second question was concerning the information gaining, the third was regarding the recalling and remembering of the information and the fourth was about the arrangement of the teaching methods (Table.1).

At the end of the semester the students sat for three exams, lecture based examination, practical exam and PBL based examination. Finally, the students perceptions about the course and the different teaching methods was compared to their performance in the three exams.

\section{Results}

\subsection{Students Perceptions}

Regarding the first question; the best teaching method for the students, $7(11.9 \%)$ stated that the lectures were the best teaching method, $22(37.3 \%)$ were with the practical sessions, $19(32.2 \%)$ mentioned that the best method for them was the problem based learning sessions and eleven students (18.6\%) stated that the three teaching methods were not the best teaching method for them. The students response for the first 
question showed that the best way of teaching is to follow multiple teaching methods in one course in order to satisfy the majority of the students (Table.1).

Regarding the second question and the perception of the students about the easiest knowledge gaining method; 35 of the students (59.3\%) mentioned that the easiest knowledge gaining method for them was the lecture, $13(22 \%)$ expressed that the practical session information were easy to gain, 10 students $(16.9 \%)$ voted for the information of the problem based learning sessions and one student $(1.7 \%)$ stated that the knowledge of all the three teaching methods was easy to gain The analysis of the second question in the questionnaire reflected the need of adopting different teaching styles in order to satisfy the students need (Table.1).

The analysis of which of the information was unforgettable and easy to recall was as follows: 24 (40.6\%) expressed that the information of the problem based learning sessions was easy to recall and difficult to forget followed by the information of the practical sessions $(17,28.8 \%)$ and lectures $(9,15.3 \%)$ and $9(15.3 \%)$ stated the information of all the three methods was difficult to forget and can be easily recalled (Table.1).

Concerning the organization of the course and the different teaching methods used, $17(28.8 \%)$ felt that the organization was excellent, $25(42.4 \%)$ registered good organization, 16 $(27.1 \%)$ stated that the arrangement of the course was acceptable and one student $(1.7 \%)$ ticked for the poorly organized option. The bulk of the students mentioned that the arrangement was either excellent, good or acceptable which means that the arrangement of the course did not affect the implementation of the different teaching methods (Table.1).

\subsection{Students Performance in the Final Exams}

The results of the students in the final exams of the lecture and problem based learning were comparable since general success percentage was $82.5 \%$ each. The performance of the students in the practical exam was better than the other two exams $(95.2 \%)$. The average and the standard deviation of the marks in the three exams was decreasing as follows; practical exam $(79.5,11)$, PBL based exam $(72.2,14.3)$ and lecture based exam $(68.4,10.7)$. The mean mark reflects the general performance of the students i.e. the students performance was better in the practical exam followed by the
PBL based exam and finally the lecture based exam (Table.1). The same pattern of the mean marks was seen in the number of the students who scored $\mathrm{A}$ and $\mathrm{B}$ while the number of students who scored $\mathrm{C}, \mathrm{D}$ and $\mathrm{F}$ was increasing from the practical through the PBL and to the lecture based exams (Table.2).

Table 1. The questionnaire questions and the perceptions of the students.

\begin{tabular}{|c|c|c|c|}
\hline \multicolumn{2}{|c|}{$\begin{array}{l}\text { Which of the following is the best } \\
\text { teaching method for you? }\end{array}$} & \multicolumn{2}{|c|}{$\begin{array}{l}\text { Knowledge is easily obtained from } \\
\text { the: }\end{array}$} \\
\hline Lectures & 07 & Lectures. & 35 \\
\hline Practical sessions. & 22 & Practical sessions. & 13 \\
\hline $\begin{array}{l}\text { Problem based } \\
\text { sessions. }\end{array}$ & 19 & $\begin{array}{l}\text { Problem } \\
\text { learning. }\end{array}$ & 10 \\
\hline Non of the above. & 11 & All of the above. & 01 \\
\hline \multicolumn{2}{|c|}{$\begin{array}{l}\text { Knowledge is difficult to forget and } \\
\text { easily recalled from the: }\end{array}$} & \multicolumn{2}{|c|}{$\begin{array}{l}\text { The arrangement of the teaching } \\
\text { methods was: }\end{array}$} \\
\hline Lectures. & 09 & Excellent. & 17 \\
\hline Practical sessions. & 17 & Good. & 25 \\
\hline $\begin{array}{l}\text { Problem based } \\
\text { learning. }\end{array}$ & 24 & Acceptable. & 16 \\
\hline All of the above. & 09 & Poor. & 01 \\
\hline
\end{tabular}

The comparison of the mean marks of three exams showed that there was statistically significant difference between lecture based and problem based exams ( $p-$ value $=0.033$ ), lecture based and practical exams ( $\mathrm{p}$ - value 0.000) and between problem based and practical exams ( $\mathrm{p}$ - value 0.000).

From the results presented in table.1, it is clear that the performance of the students in the exams was better in the practical exam followed by the PBL based exam and the lecture based exam.

By comparing the students perceptions and their results in the final exams, the results in the three exams reflected the answer of the students for question one; the highest number of the students was with the practical sessions followed by the problem based learning session and finally the lectures and the performance of the students in the three exam followed the same pattern. Unlike the better teaching method for the students, the number of students was decreasing when answering the question of the easily recalled information as follows; Knowledge of the PBL, practical sessions and finally the lecture based knowledge, however, this result is not similar to the performance of the students in the final exams.

Table 2. General facts of the three exams results.

\begin{tabular}{|c|c|c|c|c|c|c|c|c|c|}
\hline & Marks range & Mean mark & STD & $A(90-100)$ & B( 80- 89) & $\mathrm{C}(70-79)$ & $D(60-69)$ & F 60 & Pass percent \\
\hline Lecture based exam & $43-90$ & 68.4 & 10.7 & 3 & 6 & 24 & 19 & 11 & $82.5 \%$ \\
\hline Problem based exam & $35-100$ & 72.2 & 14.3 & 8 & 13 & 23 & 8 & 11 & $82.5 \%$ \\
\hline Practical exam & $55-100$ & 79.5 & 11.0 & 13 & 24 & 18 & 5 & 3 & $95.2 \%$ \\
\hline
\end{tabular}

\section{Discussion}

We did not obtain any previous study comparing between the perceptions of the students about the three teaching methods; lectures, practical sessions and problem based learning sessions. However, most of the previous studies were comparing between lectures and PBL sessions.

We have found that the preferred teaching methods were practical sessions, problem based learning sessions and lectures sequentially. Some of our students were not satisfied by all the three methods.

In the experience of the university of Rochester School of medicine and dentistry, the students were very excited by the 
problem based learning of biochemistry course and they explored the integration of biochemistry, cell biology, molecular genetics and medicine [11]. Coral pepper concluded that the majority of hid students indicated that they enjoyed the PBL sessions and that it enhanced their university learning [6]. In an attempt from Harold B. White in 2007 [12] to know the impression of his students about a problem based course and what would they tell their fellows about the course, he found that the students comments are categorized to different responses. The impression of his students were ranging from their opinion about the course and their reactions towards it, some commented on the amount of work needed and some commented on the learning process of the problem based learning. Harold B. White in 2009 [13] mentioned that good students in a lecture based teaching system found the PBL was painful and caused frustration, however, curious students were very impressive by the PBL .

Regarding the performance of the students in the three exams, our students performance was better in the practical exam followed by the PBL based exam and then the lecture based exam. However a previous study stated that the student performance in a problem oriented pharmacobiochemistry course was significantly better than their performance in a lecture based course [14,1]. Unlike our findings, Khoshnevisasl P and his colleagues in 2014 [15] mentioned that There was no significant difference between students performance in a lecture based exam and a problem based learning sessions exam .

The practical sessions are the leading preferred teaching method by our students and their performance was the better in the practical exam. However, Mani Naiker and his colleagues stated that, the laboratory work is considered by the students as a very essential and interesting teaching method which enhance their understanding of theoretical concepts [16].

We have reached to the fact that in order to obtain better student performance, different teaching methods should be adopted in one course. Similar to our conclusion Alexandre B and his research team indicated that, the use of different educational methods is effective in improving students performance [17].

\section{Conclusions}

1. The best teaching methods for the students were the practical sessions, problem based learning sessions and the lectures sequentially.

2. $18.6 \%$ of the students were not satisfied by the practical sessions nor the problem based learning sessions neither the lectures.

3. The knowledge was easily obtained from the lectures $(59.3 \%)$, practical sessions $(22 \%)$ and the problem based learning sessions $(16.9 \%)$.

4. The knowledge was unforgettable and easily recalled from the different teaching methods in the following sequence: problem based learning sessions, practical sessions and lectures.

5. The performance of the students in the three final exams was comparable to their perceptions since the best performance was registered in the practical exam followed by the PBL based exam and the lecture based exam.

\section{References}

[1] William L. Anderson, Steven M. Mitchell, and Marcy P. Osgood. Comparison of Student Performance in Cooperative Learning and Traditional Lecture-based Biochemistry Classes. BIOCHEMISTRY AND MOLECULAR BIOLOGY EDUCATION, 2005, 33, 6, pp 387-393.

[2] Michael F. Mascolo. Beyond student-centered and teachercentered pedagogy: Teaching and learning as guided participation. Pedagogy and the Human Sciences, 2009, 1, 1, pp 3-27.

[3] Dee U. Silverthorn. A Mid lecture Student Seminar: an Activity to Break the Monotony. Advances in Physiology Education, 2006, 30, pp 262- 263.

[4] Angela C. M. Figueira, Joao B. T. Rocha. A Proposal for Teaching Undergraduate Chemistry Students Carbohydrate Biochemistry by Problem-Based Learning Activities. Biochemistry and Molecular Biology Education, 2013, pp 8187. DOI 10.1002/bmb.20745.

[5] Laura Lowe Furge, Adele Wolfson, Rodney Boyer. Innovation in the Biochemistry/Molecular Biology Laboratory. BIOCHEMISTRY AND MOLECULAR BIOLOGY EDUCATION, 2013, 41,1, 11.

[6] Coral Pepper. Implementing problem based learning in a science faculty. Issues in Educational Research , 2008, 18, 1, pp 60- 71 .

[7] Howard S. Barrows, Robyn M. Tamblyn. Problem based learning: An approach to medical education. Springer series on medical education. Vol,1, 1980. ISBN 13: 9780826128416.

[8] Cindy E. Hmelo-Silver. Problem-Based Learning: What and How Do Students Learn?. Educational Psychology Review, 2004, 16, 3, pp 235- 266.

[9] Jiqin Lian, Fengtian He. Improved Performance of Students Instructed in a Hybrid PBL Format. BIOCHEMISTRY AND MOLECULAR BIOLOGY EDUCATION, 2013, 41,1, pp 5-10.

[10] Andis Klegeris and Heather Hurren. Impact of problem-based learning in a large classroom setting: student perception and problem-solving skills. Adv Physiol Educ, 2011, 35, pp 408415 .

[11] Harold C. Smith. A Course Director's Perspectives on Problem-based Learning Curricula in Biochemistry. Acad. Med, 2002, 77, pp 1189-1198.

[12] Harold B. White. What Do Students Say About Problembased Learning. BIOCHEMISTRY AND MOLECULAR BIOLOGY EDUCATION, 2007, 35, 3, pp 211-212.

[13] Harold B. White. Cultivating Students' Curiosity Quotient with Problem-based Learning. BIOCHEMISTRY AND MOLECULAR BIOLOGY EDUCATION, 2009, 37, 4, pp 249. 
[14] Y. Guven F. Bal2, H. Issever, S. Can Trosala. A proposal for a problem-oriented pharmacobiochemistry course in dental education. Eur J Dent Educ, 2014, 18, pp 2- 6.

[15] Khoshnevisasl P, Sadeghzadeh M, Mazloomzadeh S, Hashemi Feshareki R, Ahmadiafshar A. Comparison of Problem-based Learning With Lecture-based Learning. Iran Red Crescent Med J , 2014, 16, 5, e5186.
[16] Mani Naiker, Lara Wakeling, Peter Aldred. THE RELEVANCE OF CHEMISTRY PRACTICALS - FIRST YEAR STUDENTS' PERSPECTIVE AT A REGIONAL UNIVERSITY IN VICTORIA, AUSTRALIA. Proceedings of the Australian Conference on Science and Mathematics Education, Australian National University, Sept 19th to Sept 21st, 2013, page 169-173.

[17] Alexandre B. Se', Renato M. Passos, Andre' H. Ono, Marcelo Hermes-Lima. The use of multiple tools for teaching medical biochemistry. Adv Physiol Educ , 2008, 32, pp 38-46. 